

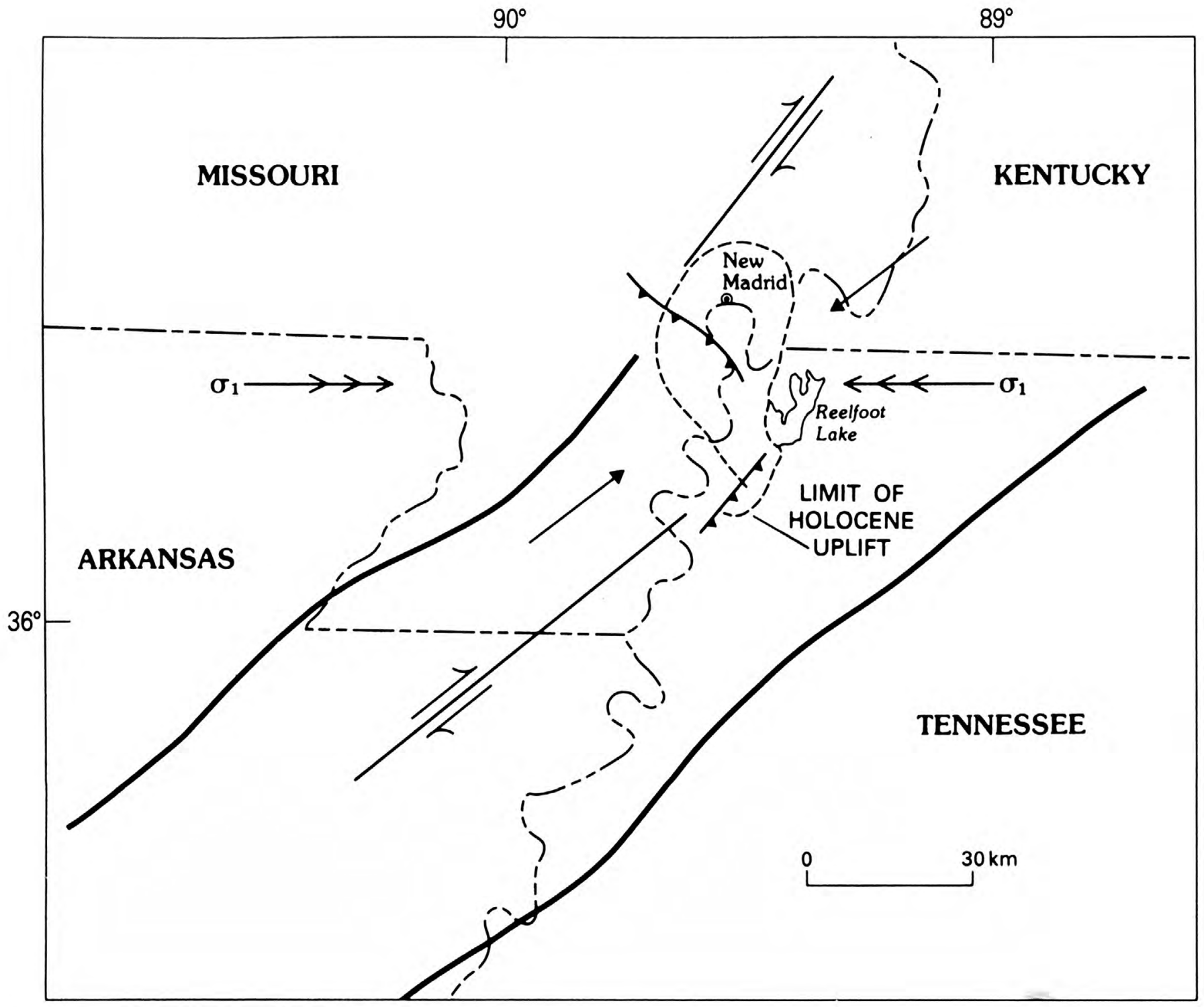

Plan view of a hypothetical model relating patterns of seismicity. sense of fault movement, and the area of Holocene uplift in the region of the New Madrid earthquakes of 1811-12. Barbed arrows indicate $\sigma_{1}$, the direction of maximum compressive stress; single arrows indicate right-lateral displacement on faults of major northeast-trending seismic zones; sawteeth indicate upthrown side of inferred reverse faults; large solid-headed arrows indicate direction of compression in region between northeast-trending en echelon faults. Figure modified from Russ (1984).

COVER: Cypress trees along the shore of Reelfoot Lake in northwestern Tennessee. Reelfoot Lake, originally an oxbow lake in an abandoned Mississippi River meander, was substantially enlarged during the major New Madrid earthquake of February 7, 1812. 


\section{Geomorphological Interpretations of Late Quaternary Terraces in Western \\ Tennessee and Their Regional Tectonic Implications}

By ROGER T. SAUCIER

THE NEW MADRID, MISSOURI, EARTHQUAKE REGIONGEOLOGICAL, SEISMOLOGICAL, AND GEOTECHNICAL STUDIES

Edited by DAVID P. RUSS and ANTHONY J. CRONE

U.S. GEOLOGICAL SURVEY PROFESSIONAL PAPER 1336-A

The morphology and gradients of four fluvial terraces may indicate Quaternary uplift over a pluton in the

New Madrid seismic zone

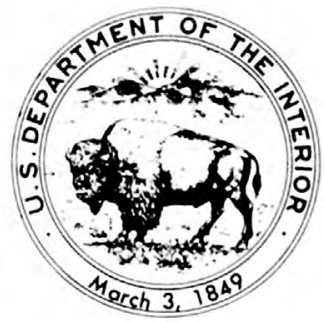




\section{DEPARTMENT OF THE INTERIOR \\ DONALD PAUL HODEL, Secretary}

\section{L'S. GEOL.OGICAI. SURVEY}

Dallas L. Peck, Director

\section{Library of Congress Cataloging in Publication Data}

Saucier, Roger T.

Geomorphological interpretations of late Quaternary terraces in western Tennessee and their regional tectonic implications.

(The New Madrid, Missouri, earthquake region-geological, seismological, and geotechnical studies) (U.S. Geological Survey professional paper ; $1336-\mathrm{A}$ )

Bibliography: p.

Supt. of Docs. no.: I 19.16:1336-A

1. Terraces (Geology)-Tennessee, West. 2. Geology, Stratigraphic-Quaternary. 3. Intrusions (Geology)—Tennessee, West. 4. Geology-Tennessee, West. I. Title. II. Series. III. Series: U.S. Geological Survey professional paper; $1336-\mathrm{A}$

GB595.T2S28 $1987 \quad 551.4^{\prime} 36^{\prime} 09768 \quad 87-600045$

For sale by the Books and Open-File Reports Section, U.S. Geological Survey,

Federal Center, Box 25425, Denver, CO 80225 


\section{FOREWORD}

The great New Madrid, Missouri, earthquakes of 1811-12 and the extended series of aftershocks that followed have focused considerable U.S. attention on the geologic stability of the interior of the North American crustal plate. These and subsequent earthquakes have shown clearly that the mid-continent is capable of generating devastating earthquake ground motions and that study of these earthquakes is essential to reducing their associated hazards. This Professional Paper presents significant new contributions to fundamental knowledge about the seismicity, tectonic framework, and earthquake hazards of the New Madrid seismic zone. Some of the chapters refine the conclusions of earlier work, further clarifying the understanding of the seismotectonics of the region.

As early as 1846, the eminent English geologist Sir Charles Lyell studied the effects of the earthquakes of 1811-12 and recognized the effects of recurrent earthquakes on the physiography and structure of the Mississippi Valley. The first comprehensive geologic investigation of the New Madrid earthquakes was made by Myron Fuller of the U.S. (ieological Survey (USGS), who published his findings in 1912. Fuller described the distribution and character of surface deformation and liquefaction features and compiled a detailed list of aftershocks and their effects.

In 1974, the USGS began multidisciplinary studies to investigate the cause of the New Madrid earthquakes and to determine the hazards and risk associated with the continuing seismicity in the region. In the same year, the Department of Earth and Atmospheric Sciences of St. Louis University began installation of a 16-station microearthquake-detection network in the Mississippi embayment (later expanded to 32 stations plus 8 additional stations in the Wabash Valley of Illinois and Indiana). The studies and seismograph network were designed to determine the temporal and spatial distribution of seismicity in the New Madrid seismic zone, to delineate the structural framework of the earthquake source zone, and to determine the recurrence rate of damaging earthquakes in the New Madrid region by investigations of surficial sediments and structures.
In 1977, the U.S. Nuclear Regulatory Commission initiated a multi-institutional seismotectonic study of the area within a 200 -mile radius of New Madrid. The study was conducted by scientists from midwestern universities and State geological surveys, in coordination with Federal agencies conducting investigations in the area. The purpose of the study was to define the structural and tectonic setting of the New Madrid seismic zone in order to evaluate earthquake risks in the siting of nuclear facilities. Geological, engineering. and seismological studies for assessing earthquake hazards and risk associated with the Mississippi River and related waterways and manmade structures have been conducted independently by scientists and engineers of the U.S. Army Corps of Engineers.

Results of many of the investigations completed in the first 8 years of study $(1974-82)$ in the northern Mississippi embayment were presented in USGS Professional Paper 12:36. These studies revealed that earthquakes in the New Madrid area occur in linear zones that arespatially associated with structures in a buried continental rift that formed in the Precambrian. Reactivation of faults along the ax is and flanks of the rift in a compressive stress field has produced uplift and many of the region's earthquakes. The buried Paleozoic surface has only minor structural relief, however, indicating that Cenozoic fault activity has been only modest or that most of the fault offset has been strike-slip. Earthquakes large enough to cause tectonic surface deformation and liquefaction features occur on the average of every $600-700$ years in the New Madrid seismic zone.

Geophysical, geological, and seismological investigations by scientists of the USGS, State geological surveys, academia, and the U.S. Army Corps of Engineers have continued in the New Madrid seismic zone since the publication of USGS Professional Paper 1236. Of particular importance have been seismicrefraction and seismic-reflection surveys; geomorphic analyses of river terraces and stream profiles in Tennessee, Kentucky, and Arkansas; and studies of earthquake-induced hazards such as liquefaction. 
landslides, and ground motion. Some of the new data and conclusions from these investigations are given in chapters published at irregular intervals as part of this Professional Paper 1336. These chapters provide a more complete understanding of the seismicity and tectonic evolution of the New Madrid region and the effects of hazards that the earthquakes produce; consequently, they will enhance the effort to implement loss-reduction measures in an economical and effective manner.

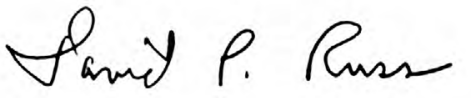

David P.Russ

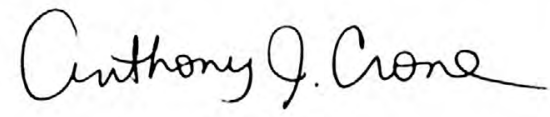

Anthony J. Crone

Editors 


\section{CONTENTS}

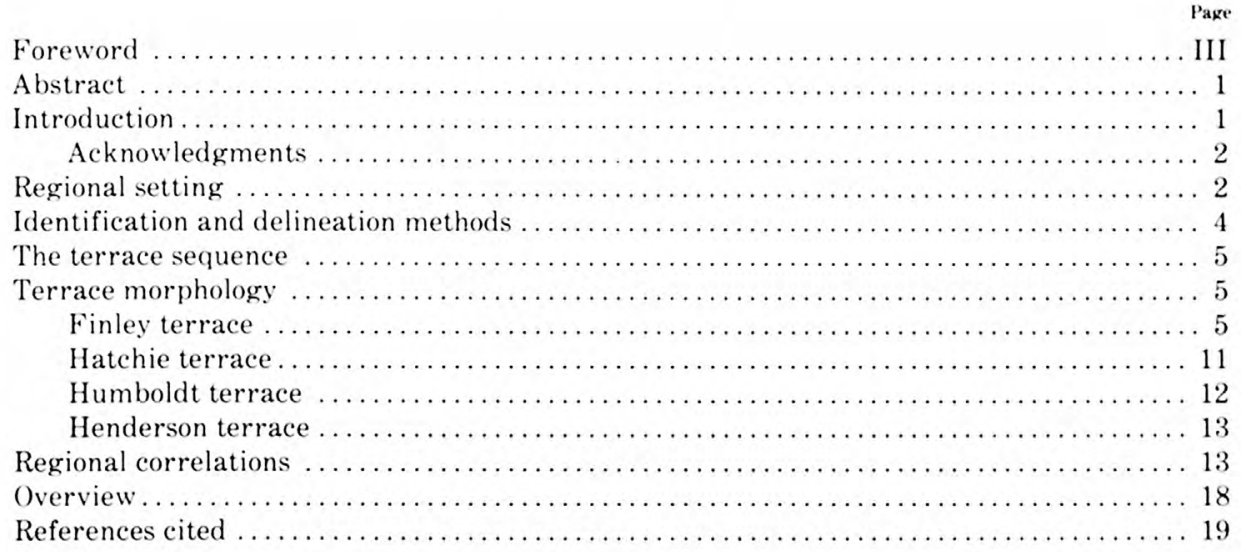

\section{ILLUSTRATIONS}

FIgURE 1. Map showing locations of the five Mississippi River tributaries in western Tennessee whose terraces were studied for

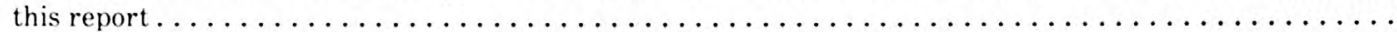

2-5. Maps showing the distribution of terraces along the:

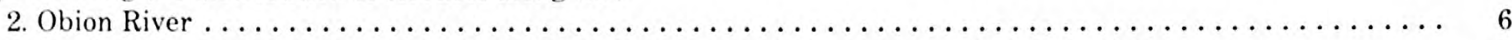

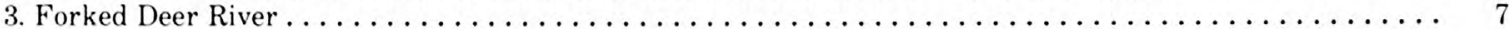

4. Hatchie River $\ldots \ldots \ldots \ldots \ldots \ldots \ldots \ldots \ldots \ldots \ldots \ldots \ldots \ldots \ldots \ldots \ldots \ldots \ldots \ldots \ldots \ldots \ldots \ldots$

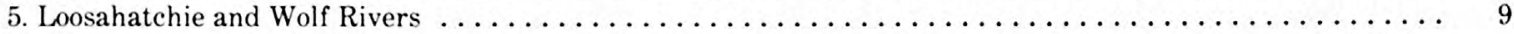

6. Downvalley terrace and flood-plain profiles for the five rivers in western Tennessee whose terraces were studied for

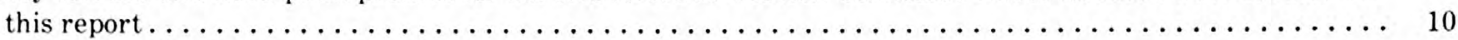

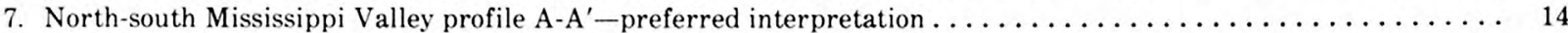

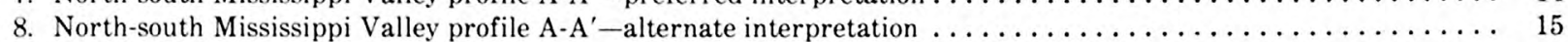





\title{
GEOMORPHOLOGICAL INTERPRETATIONS OF LATE QUATERNARY TERRACES IN WESTERN TENNESSEE AND THEIR REGIONAL TECTONIC IMPLICATIONS
}

\author{
By Roger T. Saucier ${ }^{1}$
}

ABSIRAC:I

By use of large-scale topographic maps and traditional techniques of geomorphology, a series of stream terraces was identified and delineated on the Obion, Forked Deer, Hatchie. Loosahatchie, and Wolf Rivers in western Tennessee. From lowest and voungest to highest and oldest, they are designated the Finley, Hatchie, Humboldt, and Henderson terraces. The areal extent and continuity of each of these relict flood plains are ample to permit reconstruction of former elevations and valley slopes.

Downvalley gradients of the terraces and morphology are strongly indicative of the processes and events that influenced terrace formation. Nil gradients for several tens of kilometers upstream from the Mississippi alluvial valley on the Finley and Hatchie terraces and shoreline features on the Finley terrace are interpreted as evidence that backwater flooding from the Mississippi Valley produced extensive seasonal or permanent lakes in the tributary valleys. Therefore, in part, these terraces are relict lacustrine plains. The Humboldt and Henderson terraces do not have any of these characteristics and are interpreted as being entirely of fluvial origin. All terraces are capped by a veneer of loess representing one or more episodes of deposition.

Interstream terrace correlations made by using only geomorphic evidence are not definitive, and two interpretations are nearly equally viable. One of these has potentially significant regional tectonic implications because it suggests Quaternary uplift in the vicinity of a known pluton along the flank of the major rift in the New Madrid seismic zone. However, the preferred interpretation suggests that no appreciable regional structural deformation has

\footnotetext{
II.S. Army Engineer Waterways Experiment Station, Vicksburg, MS 39180.
}

taken place. Neither interpretation indicates Quaternary deformation in the upland area relative to the Mississippi alluvial valley.

Topographic relationships of the terraces to features resulting from the sequence of Pleistocene aggradation and degradation in the Mississippi Valley indicate correlation of the Finley terrace with the early Wisconsinan episode of outwash deposition. Several lines of evidence suggest correlation of the Hatchie terrace with the Prairie terrace of the lower Mississippi Valley, which is Sangamonian in age. $\mathrm{By}$ inference, the Humboldt terrace could be of Yarmouthian age.

\section{INTRODUCTION}

In 1970, Saucier and Fleetwood called attention to the status of knowledge about Quaternary depositional terraces of fluvial origin in the Gulf of Mexico Coast and lower Mississippi Valley regions. At the time, problems were recognized in nomenclature, chronology, and regional correlations with the interpretations of Fisk (1939), but no alternatives to Fisk's work were widely accepted. Since then, the problems have increased to the point where some people are reluctant to accept the basic Fiskian terrace sequence. Studies of terraces (largely site specific) are continuing to produce information on details of lithology, sand and gravel source areas, faunal content, and absolute age, and this new information requires new concepts of terrace formation and chronology. 
Ironically, although investigators are scrutinizing certain terraces and applying new techniques to squeeze more evidence from them, entire sequences in parts of the lower Mississippi Valley either have gone essentially unnoticed or have been ignored. For example, terraces in the Ouachita River area were first studied in the late 1960's (Fleetwood, 1969; Saucier and Fleetwood, 1970), and terraces along the Arkansas River and several other Mississippi River tributaries are still unstudied. Because all terraces were controlled by the same factors (for example, sealevel variations and base-level changes in the Mississippi alluvial valley related to glaciation and deglaciation), sound terrace concepts must be based on an appreciation of the nature and distribution of the entire terrace system.

This paper is an initial attempt to reduce the basic knowledge deficit in one more part of the lower Mississippi Valley - western Tennessee. With only one exception (Smith, 1979), terraces in this area have received only passing mention in the technical literature (Saucier, 1964, 1974), and they have not been accurately delineated or recognized even on the latest and most detailed geologic map available (Miller and others, 1966). To date, students of the Quaternary of west Tennessee have focused almost exclusively on the origin of the upland gravel blanket (Potter, 1955; Roberts, 1928) and have not considered lower units that are more closely associated with present drainage.

The information in this paper was obtained only by geomorphological analysis of the terraces based on a detailed examination of maps and aerial photographs and a general knowledge of the area. No field work was done, and no effort was made to collect subsurface information. No attempt was made to interpret terrace occurrence or characteristics in terms of variations in the hydrology of the drainage basins. Thus, field work and studies of hydrology and terrace lithology, petrology, paleontology, and other characteristics are desirable future endeavors that I hope will be encouraged by this initial paper. Such investigations would be relevant and timely in view of the recent resurgence of interest in Quaternary tectonism in the New Madrid earthquake zone immediately adjacent to the area considered in this paper (Russ, 1979). Terrace distribution and morphology and interstream correlations are valuable clues for deciphering the influences of external controls such as base-level changes, climatic change, and regional deformation.

The rest of this paper contains descriptions of (1) the regional setting of the rivers whose terraces were studied, (2) the methods used to identify the terraces, and (3) the terraces themselves. These descriptions are followed by two possible interpretations of interstream terrace correlations and a discussion of how such terrace correlations may provide information on Quaternary events in the Mississippi alluvial valley and on Quaternary tectonism in the New Madrid seismic zone.

\section{ACKNOWLEDGMENTS}

I am grateful for the critical reviews of this paper and assistance in its publication provided by A.J. Crone, E.H. Grissinger, J.T. Hack, M.D. Harvey, D.P. Russ, S.A. Schumm, and B.R. Winkley. I also appreciate assistance in the preparation of the manuscript rendered by personnel of the Publications and Graphic Arts Division and the Environmental Information Analysis Center of the U.S. Army Engineer Waterways Experiment Station, Vicksburg, Miss. Approval by the Office, Chief of Engineers, for publication is acknowledged.

\section{REGIONAL SETTING}

Terraces along five westward-flowing rivers and their principal tributaries (called forks) in western Tennessee are the focus of this paper (fig. 1). Each river rises in hilly terrain in outcropping Tertiary and Cretaceous formations just west of the Tennessee River and crosses the eastern part of the Mississippi embayment to become tributary to the Mississippi River at the eastern edge of its Holocene alluvial valley (Cushing and others, 1964). These rivers have formed valleys of significant size in a westward-thickening sequence of poorly consolidated post-Paleozoic embayment sediments that attains a thickness of about $700 \mathrm{~m}$ along the embayment axis near the Mississippi River (Zoback, 1979).

In the eastern part of the area shown in figure 1, north-northeast-trending Tertiary formations composed of sand, silt, clay, and lignite deposited in terrestrial to nearshore-marine environments compose the interfluves and are the source of the stream alluvium (Miller and others, 1966; Parks, 1971). Discontinuous deposits of fluvial sand, silt, and gravel of early Quaternary and late Tertiary age are present locally as remnants of once more continuous formations. In the western part of the area, west of a northnortheast-trending line through Jackson, Tenn. (fig. 1 ), virtually the entire landscape is mantled with loess (Wascher and others, 1948; Miller and others, 1966). At least three episodes of deposition (Leighton and Willman, 1950) are represented in this westwardthickening loess layer. It reaches an average maximum thickness of more than $5 \mathrm{~m}$ at the edge of the Mississippi alluvial valley, and it has measured maximum thick- 


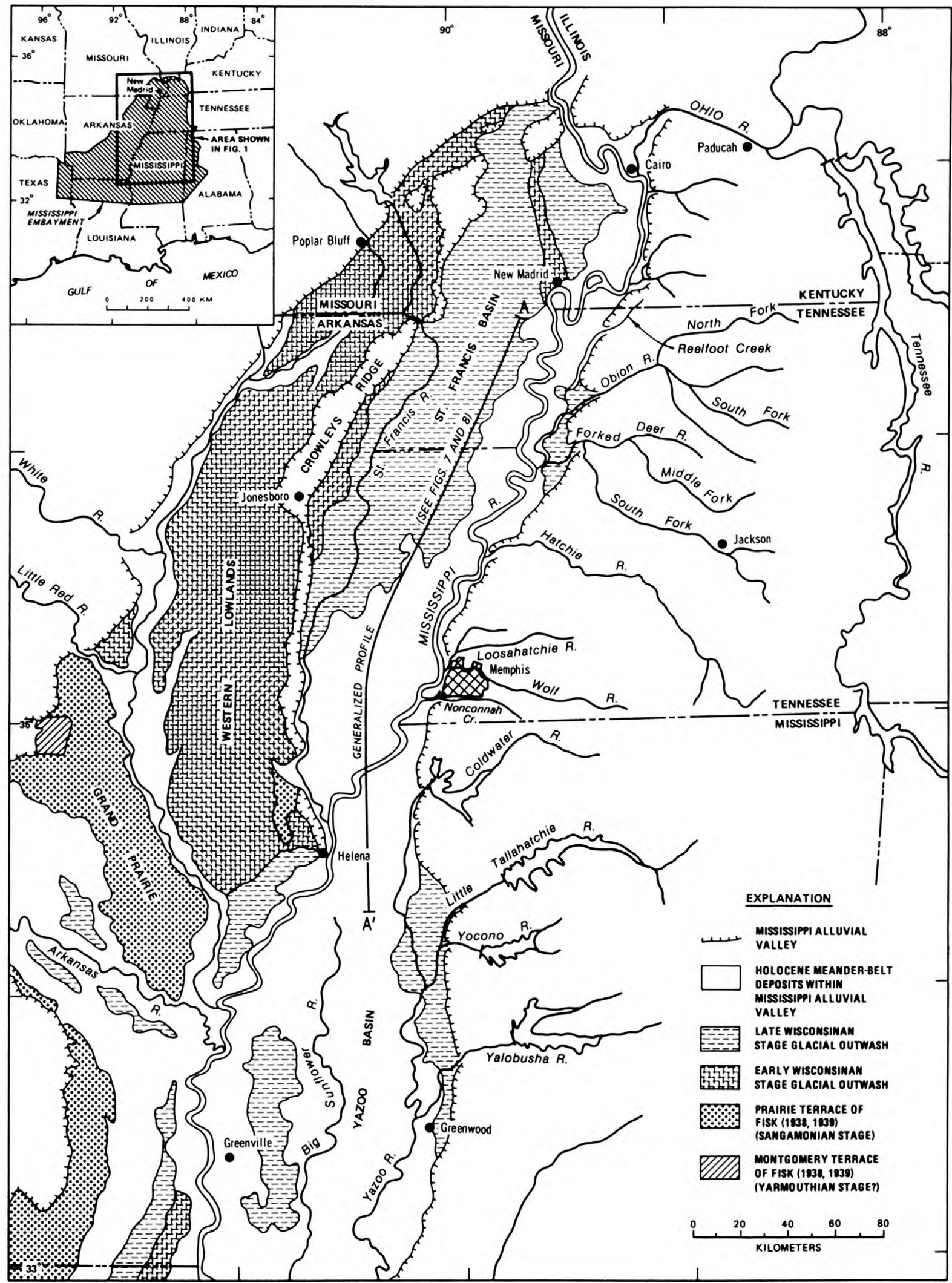

FIGURE 1.-Locations of the five rivers in western Tennessee whose terraces were studied for this report: the rivers become tributary to the Mississippi River near the eastern edge of its Holocene alluvial valley. Also shown is the distribution of terrace, glacial-outwash, and Holocene meander-belt deposits in part of the alluvial valley. 
nesses in outcrops of as much as $17 \mathrm{~m}$ (Wascher and others, 1948).

The highest elevations 2 ( 165 to $180 \mathrm{~m}$ ) and the most maturely dissected terrain, in the form of a moderately hilly landscape, occur in the easternmost part of the area. Elevations and relief decline to the west. In a belt 10 to $15 \mathrm{~km}$ wide a similar distance east of the Mississippi alluvial valley, elevations do not exceed $120 \mathrm{~m}$ and the landscape is more gently rolling. However, immediately east of the alluvial valley, elevations are slightly higher (150 m or more), and the terrain is strongly hilly and steeply gullied. This terrain is a reflection both of the loess veneer, which is easily eroded, and of an inversion of topography caused by differential weathering of the Tertiary and Cretaceous deposits (Russ, 1982).

All present drainage is well incised into the landscape, and major interfluves are 30 to $50 \mathrm{~m}$ above the flood plains of the major rivers. Average flood-plain gradients of the larger rivers range generally from 30 to $45 \mathrm{~cm} / \mathrm{km}$; however, actual stream gradients are appreciably lower because the streams have tightly meandering patterns. The modern flood plains of the five rivers discussed in this paper are conspicuously wide and flat, so that the present rivers appear to be grossly underfit. However, the degree of fit is a complex matter subject to definition, age, stream behavior, and other factors discussed below.

Of the five river systems examined, the Hatchie, Obion, and Forked Deer are the largest; each has a drainage-basin area of between 5,000 and $7,000 \mathrm{~km}^{2}$. The Loosahatchie and Wolf Rivers are considerably smaller, and each drains about $2,000 \mathrm{~km}^{2}$ (Lower Mississippi Region Comprehensive Coordinating Study Committee, 1974). Hydrologically, the five rivers are similar to other streams in this humid subtropical climatic zone, having a pronounced late winter-early spring discharge maximum that may be several hundred times the low-flow discharge. The mean annual flows of the streams range from 30 to $136 \mathrm{~m}^{3} / \mathrm{s}$.

\section{IDENTIFICATION AND DELINEATION METHODS}

Large-scale $(1: 24,000)$ topographic maps published by the U.S. Geological Survey were the primary data source used to identify and delineate the terraces. In all, 105 maps were used, most of which had 10-ft (3.3$\mathrm{m})$ contour intervals and supplemental half-interval contours for low-relief areas. A few maps of the more rugged eastern part of the area had $20-\mathrm{ft}(6.6-\mathrm{m})$ contour intervals. Additional data of limited value were obtained from 1:62,500-scale mosaics of U.S.

\footnotetext{
${ }^{2}$ All elevations in this report are given in meters above sea level; that is, the National Geodetic Vertical Datum of 1929
}

Department of Agriculture air photographs taken at various times during the past several decades.

Traditional techniques of geomorphology were used in terrace recognition. In the only previous mapping of note, Smith (1979) identified terraces solely by the construction of crossvalley profiles on which terrace position relative to the present river was determined. In my study, terraces were recognized from crossvalley profiles too, but additional recognition criteria included plan form, locations and configurations of escarpments and topographic breaks, degree of dissection, uniformity of elevations, relative height above flood plains, and drainage patterns. Modern county soil surveys, a normally valuable tool, exist for only a small part of the area. Consequently, they were of no appreciable value in this study. Another common criterion, land use, was not helpful because in this region, the physical landscape is not an important control on man's activities such as agriculture, road location, and settlement.

An initial stage of map interpretation established the presence of terraces, their basic distribution, and topographic relationships. This stage included constructing preliminary downvalley profiles to determine slopes and elevations of mapped terrace segments. A subsequent stage was thereby possible in which the profiles were used to verify correlations and to reexamine the topographic maps for smaller or more obscure remnants not detected in the initial stage. The additional map data, in turn, were used to refine the profiles and fill data gaps. In questionable situations, this process was repeated several more times. To avoid undesirable bias in interpretations, each stage was completed for all five rivers before the next stage was initiated.

The downvalley profiles represent an attempt to reconstruct original relict flood-plain elevations; thus, the elevations determined for given terrace segments may or may not precisely match present prevailing elevations. On the inner terrace margins (toward the upland interfluves), present average elevations usually exceed the determined original elevations because of the presence of well-developed alluvial fans and aprons. Along the outer terrace margins, erosion and stream dissection have resulted in present average elevations being lower than original elevations. I made subjective allowances for these conditions, and possible errors attributable to them are probably minor. A more important factor is the thickness of the loess veneer. The extent of loess on the terraces has not been determined; we do not know even whether the deposits are thicker on the older terraces or whether their thickness varies longitudinally along the valleys. Errors on the high side by an estimated 1 to $3 \mathrm{~m}$ in the 
downvalley profiles may be present because of this ignorance about loess thickness.

\section{THE TERRACE SEQUENCE}

After the large-scale maps and downvalley profiles were completed, composite maps at a scale of 1:250,000 were prepared for each river system. This synoptic view affirmed the presence of terraces of sufficient areal extent and continuity to warrant the designation of from two to four discrete terrace units or formations on each river system. On the basis of relative elevations and morphological characteristics (which are discussed more fully below), interriver correlations were apparent in this early stage of the investigation. I concluded that these correlations (although they have problems as discussed below) are sufficiently sound to justify the use of proper names for the terraces rather than the more tenuous and confusing alternative of alphabetic or numeric designations by river system (Smith, 1979). The four terraces named are, from youngest to oldest, the Finley, Hatchie, Humboldt, and Henderson. The Hatchie terrace was named for the Hatchie River, along which the terrace forms wide continuous outcrops. The Finley, Humboldt, and Henderson terraces were named for towns on the terraces (fig. 3). The terraces at the three towns and along the Hatchie River should not be considered type localities in the geological sense because I have no specific knowledge of the stratigraphy of the terraces at these or other localities.

The composite mapping results are shown in figures 2 through 5. Although the scale of presentation is small, the reader can feel safe in enlarging these maps to a more usable scale as they were compiled through photographic reduction and were carefully and accurately drafted. Because of limitations imposed by both the scale of the maps used for interpretation and the scale of the maps used herein for presentation, terrace remnants less than $1 \mathrm{~km}^{2}$ in area were not delineated.

Some significant characteristics of these terraces are apparent from just their geographic distribution. All are paired terraces, indicating episodic responses to base-level control rather than continuous adjustment. Also, the younger (lower) terraces are generally better developed and better preserved along the lower reaches of the rivers. This preservation pattern suggests that a major base-level control was localized at the lower end of the rivers and was not uniformly regional. As is shown below, downstream divergence of terrace gradients supports the idea of localized base-level control. The active river flood plains have narrowed with time. This narrowing is particularly evident on the Hatchie River (fig. 4) where the modern (Holocene) flood plain is in places one-half to one-third the width of the oldest one as marked by the extent of the terraces. The Hatchie River terrace sequence is unique in several respects, one of the more obvious being the extent and continuity of the Hatchie terrace.

\section{TERRACE MORPHOLOGY}

The reconstructed downvalley profiles are critical to an understanding of terrace origin and well illustrate aspects of terrace morphology. Figure 6 is a compilation of profiles for each river system or major fork of a river system. Profile distances are measured along smoothed valley lines and are shown in plan in figures 2-5. For each river, kilometer 0 represents the extreme eastern edge of the Mississippi alluvial valley. In general, the profiles agree well with my interpretations of the crossvalley profiles constructed by Smith (1979); differences in detail are due to different methods used both in determining elevations and in correlating terraces.

\section{FINLEY TERRACE}

On all rivers, the Finley terrace is the youngest and the easiest to recognize and delineate because of its well-preserved flat surface and distinctive scarps separating it from both the Holocene flood plain and adjacent uplands or older terraces. At the valley mouths, the terrace surface is 3 to $7 \mathrm{~m}$ above the Holocene flood-plain level (fig. 6). From these points, the terrace extends upstream, at first with a characteristic nil gradient and thence, on all but the Loosahatchie and Wolf Rivers, with a very low gradient. Because this low gradient is less than that of the Holocene flood plain, the two eventually merge. Careful interpretations of maps and aerial photographs of the merger locations leave no doubt that the "terrace" extends further upstream, but thereafter it is buried (and locally reworked) beneath a progressively thickening veneer of Holocene alluvium. The greatest longitudinal extent of the Finley terrace as a topographic feature is on the South Fork of Forked Deer River, where it can be traced for more than $50 \mathrm{~km}$ (fig. 3).

One conspicuous aspect of the morphology of this terrace is the presence on the Forked Deer River, and, to a lesser extent, on the Obion River, of an actual reversal in gradient for several kilometers upstream from the Mississippi alluvial valley. Even with the limitations of the $10-\mathrm{ft}(3.3-\mathrm{m})$ contour interval, the topographic maps show that the average terrace elevations at the immediate valley mouths are 1 to $2 \mathrm{~m}$ 


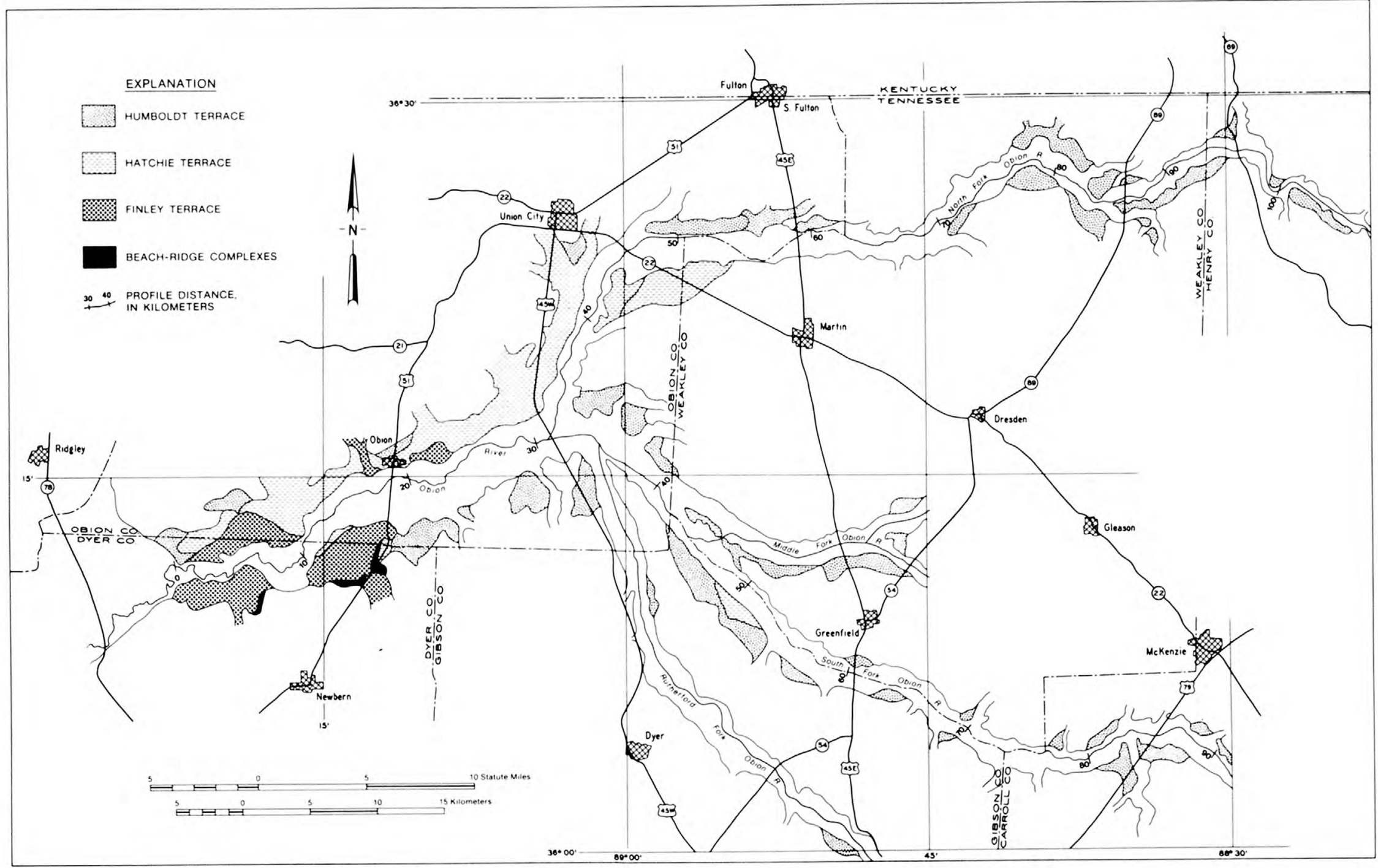

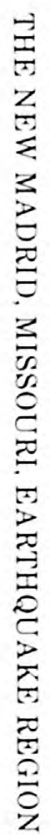

FIGiRE: 2.-Terraces along the Obion River. Downvalley profiles of terraces and flood plains for the North and South Forks are shown in figure 6. 


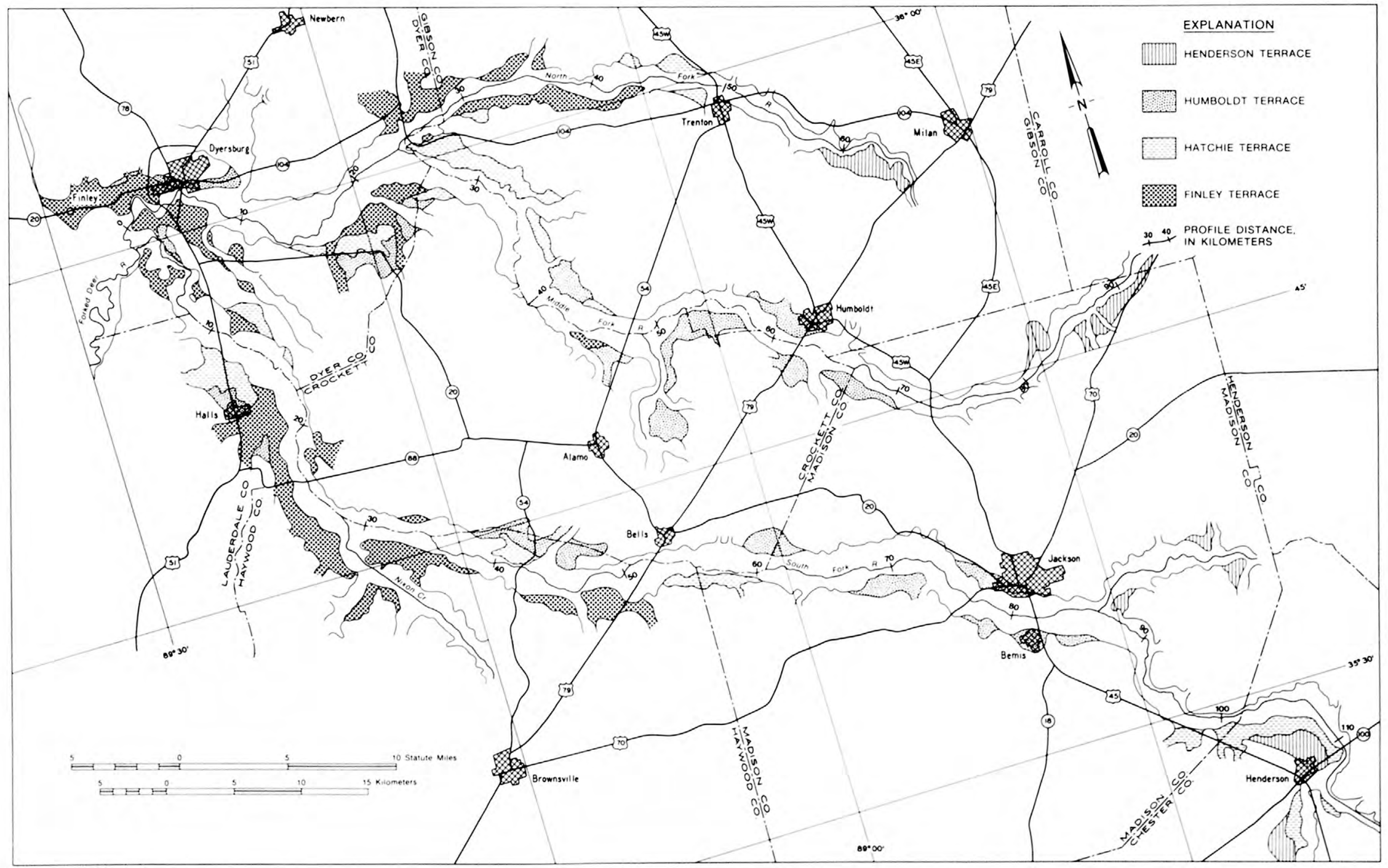

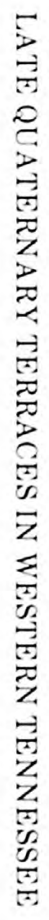

FIGit RE 3.-Terraces along the Forked Deer River. Downvalley profiles of terraces and flood plains for the North. Middle, and South Forks are shown in figure 6 


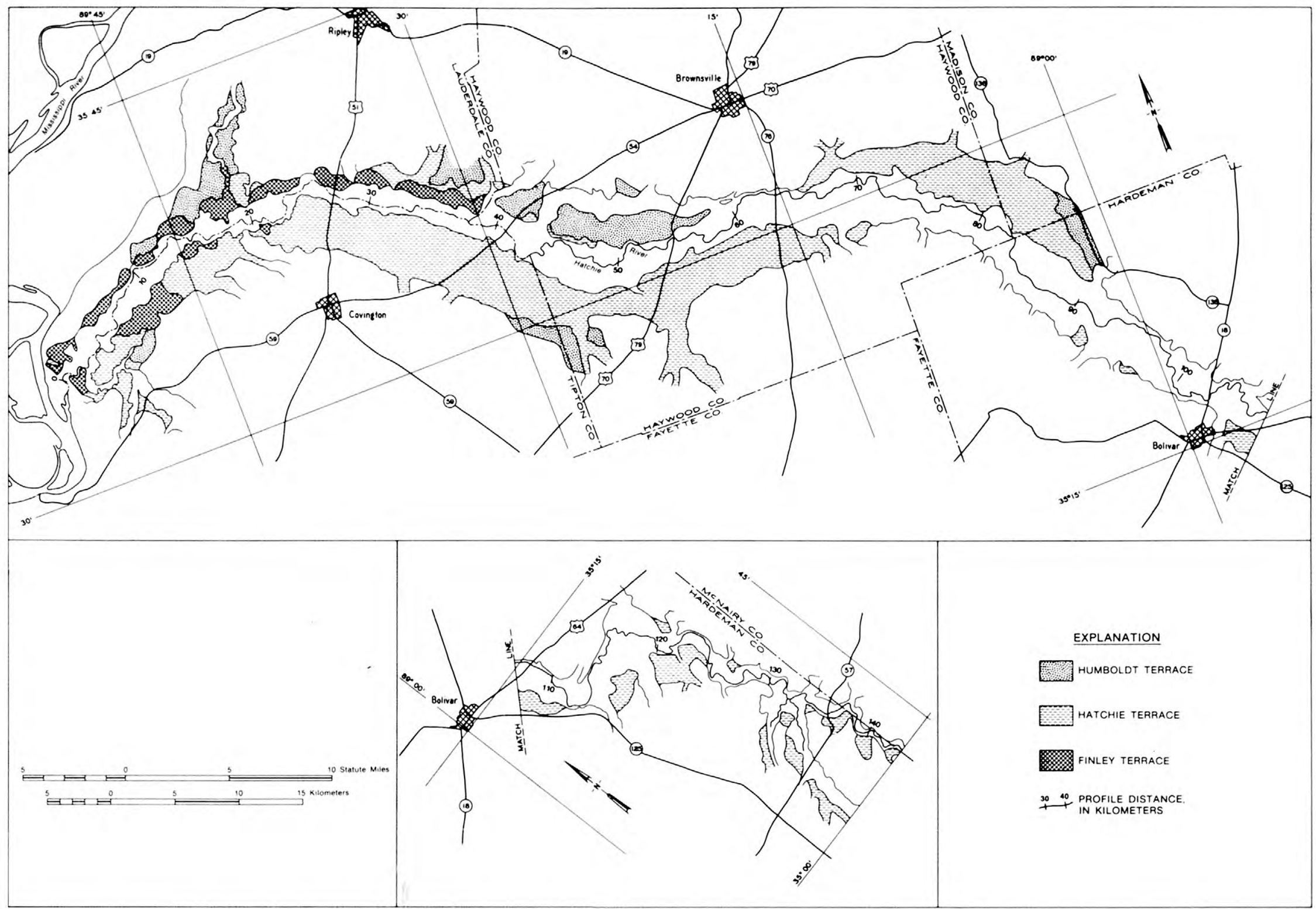

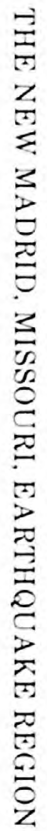

FIGURE 4.-Terraces along the Hatchie River. Downvalley profile for the terraces and flood plain is shown in figure 6 . 


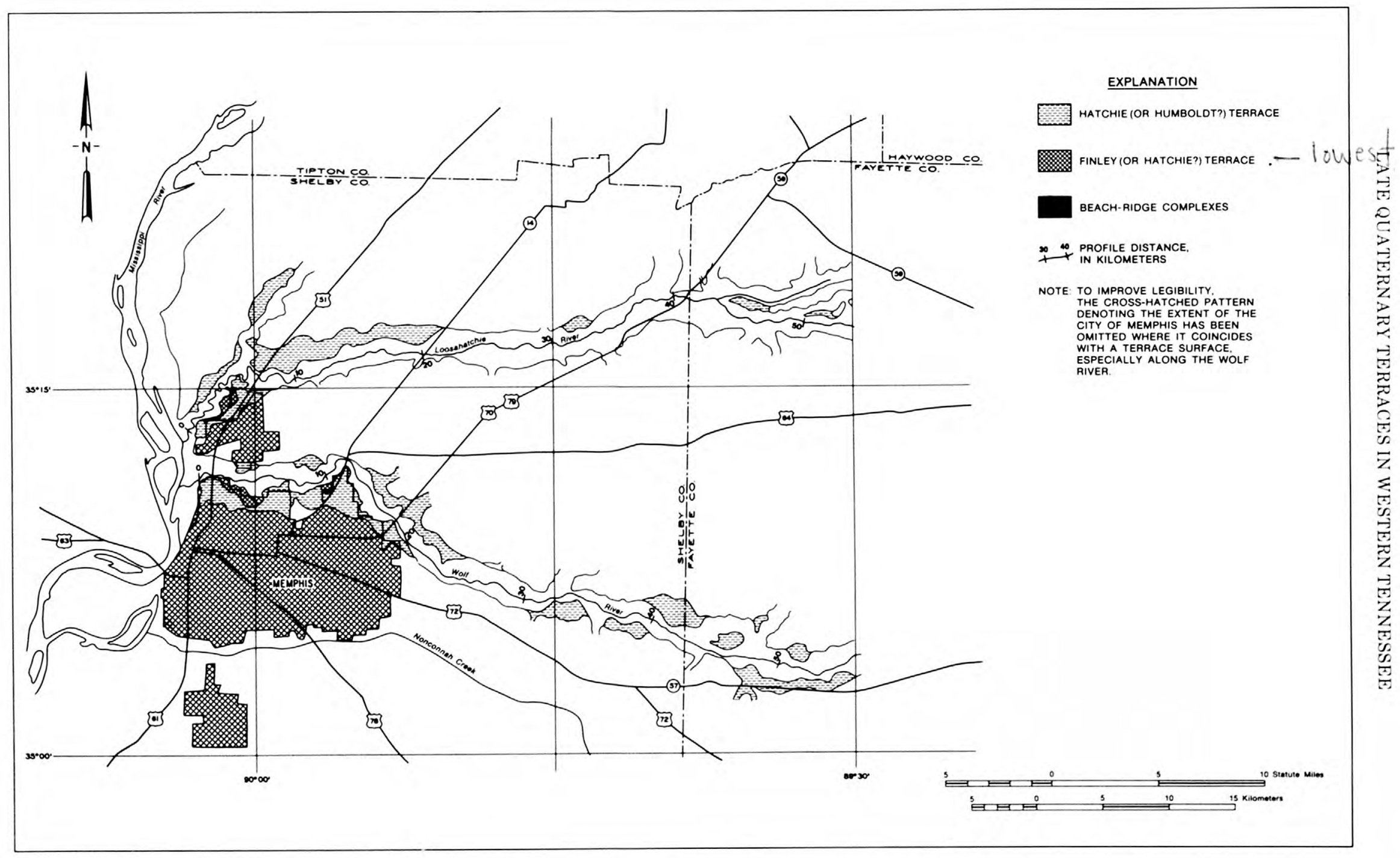

FIGURE 5.-Terraces along the Loosahatchie and Wolf Rivers. Downvalley profiles of terraces and flood plains for both rivers are shown in figure 6. 

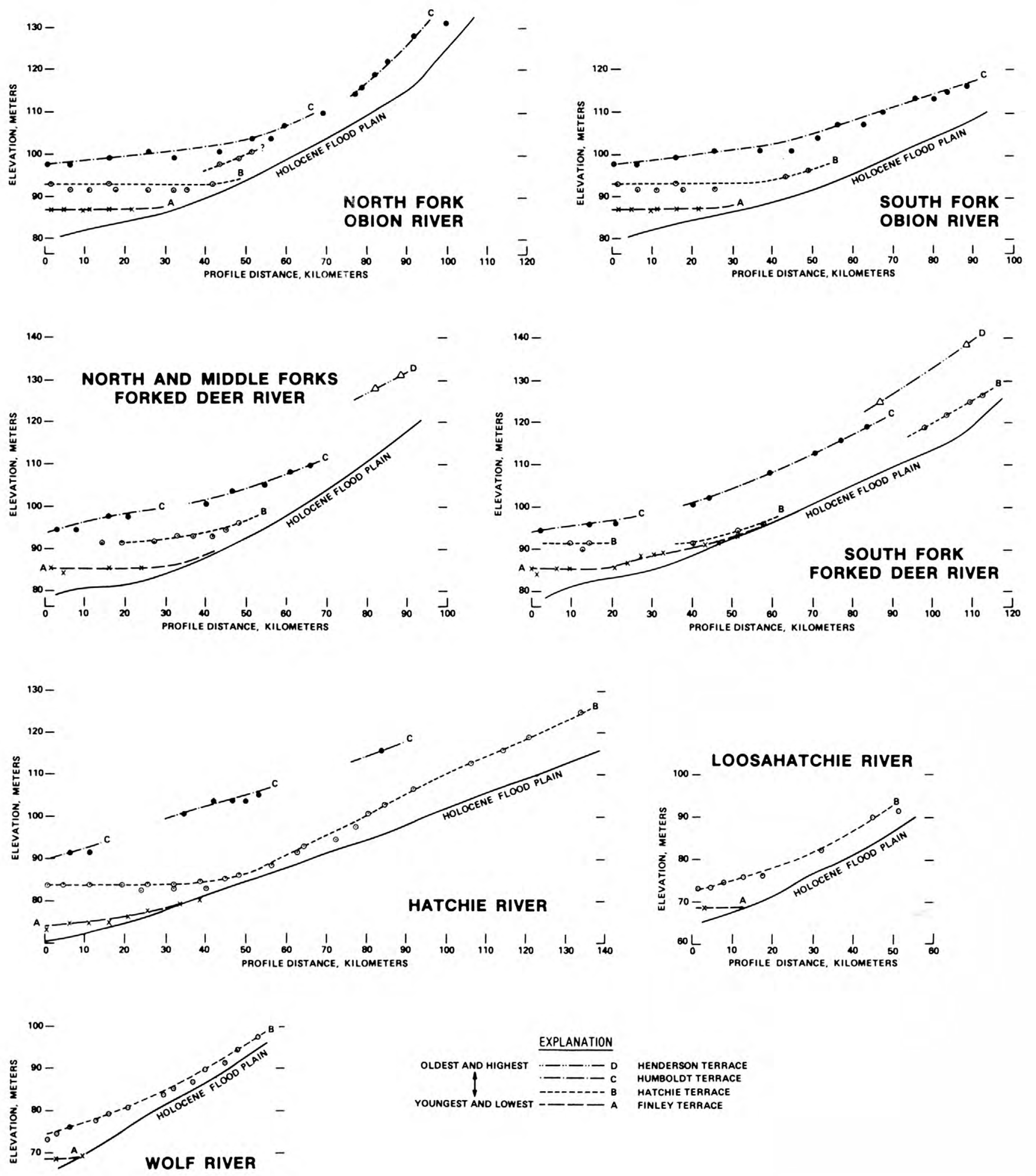

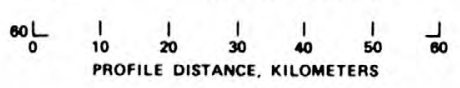

FICIRE 6. - Downvalley profiles of terraces and flood plains for the five rivers in western Tennessee whose terraces were studied for this report. Elevations in meters above mean sea level. 
higher than those a short distance upvalley; hence, a slight "lip" is present at the edge of the Mississippi alluvial valley. Morphologically, this could be cited as evidence of Mississippi Valley alluvium ${ }^{3}$ that was introduced into the mouths of the tributary valleys. However, at least some of the sediments in this area have been identified as loess (D.P. Russ, 1983, written commun.).

Along the Obion and Loosahatchie Rivers (figs. 2, 5), features tentatively identified as beach-ridge complexes have been delineated. These are linear zones characterized by parallel ridges and swales that occur at the upland scarps. They have reasonably accordant crest elevations about $6 \mathrm{~m}$ above the average Finley terrace surface elevation. In all morphological aspects, they resemble the lake beaches and bars that have been described from along the Ohio, Tennessee, and Clark Rivers in Kentucky and Illinois (Finch and others, 1964) and the Ouachita River in Louisiana (Saucier and Fleetwood, 1970).

The terrace topography, nil gradient, and probable beach ridges indicate that the downstream parts of the Finley terrace are primarily of lacustrine-plain origin. The lakes that produced the terrace resulted from the damming effect of an episode of rapid sedimentation (outwash deposition) and high flood stages in the Mississippi alluvial valley. The lakes probably were perennial, representing a mixture of local runoff and Mississippi Valley backwater flooding. As outwash deposition in the Mississippi Valley likely was highly variable and episodic, the lake stage must have fluctuated appreciably. Both living and drowned floodplain swamp forests must have been present periodically to varying extents.

As indicated above, this region has a loess veneer. Therefore, lacustrine sediments probably do not occur at the present terrace land surface except locally where the loess has been eroded.

In 1979, Smith mapped the Finley terrace as two units, his $\mathrm{T}_{1}$ and $\mathrm{T}_{2 \mathrm{~b}}$ levels. This recognition of two levels is easy to understand because of the abovementioned features (for example, beach ridges) that occur at different elevations and because he did not use continuous delineation techniques.

At scattered localities along each river, both the upland terrace margin and the margin adjacent to the Holocene flood plain have the form of smooth arcuate scallops. The size and configuration of the scallops, the

\footnotetext{
3."Mississippi Valley alluvium" is used intentionally rather than "Mississippi River alluvium," The Mississippi River probably remained west of Crowleys Ridge in the Western Lowlands until late Wisconsinan time. Prior to this time. the part of the Mississippi Valley east of Crowleys Ridge the St. Francis Basin) was occupied by the (Ohio River and local drainage.
}

occasional presence on the lower level of faint traces of point-bar accretion, and several relict abandoned channels clearly indicate that these features resulted from lateral migration by a meandering stream. The radii of these features suggest that the relict streams may have had discharges significantly larger than those of the present rivers.

As is discussed below, a widely distributed terrace in the Gulf of Mexico and Atlantic Coastal Plains was formed by streams carrying appreciably higher flows than those carried during the Holocene. Designated the Deweyville terrace (Gagliano and Thom, 1967; Saucier and Fleetwood, 1970), it attests that the fluvial systems showed at least one major regional response to effectively increased precipitation during the late Quaternary. In the western Tennessee area, the scallops at the lower and upper Finley terrace margins indicate that two such episodes may be in evidence, one necessarily predating the formation of the lakes and one postdating them.

\section{HATCHIE TERRACE}

In the five river systems studied, the Hatchie terrace areally is the best preserved. On the river of the same name, its extent is dramatic (fig. 4). This terrace most closely corresponds to the $\mathrm{T}_{2 \mathrm{a}}$ level as identified by Smith (1979). It is restricted to the more downstream parts of the Obion River (fig. 2) and the North and Middle Forks of Forked Deer River (fig. 3), but on other rivers, it can be traced well upstream toward the headwaters (figs. 4, 5).

Along the Hatchie River, one contiguous segment of this terrace extends for more than $45 \mathrm{~km}$ along the valley and averages 3 to $4 \mathrm{~km}$ in width (fig. 4). The surface in this area is flat to slightly undulating, and extensive swampy tracts are interrupted by low, irregular knolls and ridges. Drainage from the uplands crosses the terrace in numerous tortuous channels in a chaotic pattern. The morphology alone does not provide enough evidence for speculation about the origin or origins of the irregular topography. However, as suggested by Smith (1979), excessive sedimentation resulting from 19 th century land clearing and development may be at least in part a causal factor. Postsettlement alluvium has been documented as a major flood-plain element in other drainage systems in the Mississippi Valley area (Grissinger and others, 1982). On the other rivers in Tennessee, the topography on the Hatchie terrace is strongly influenced by the presence of alluvial fans and aprons, and local drainage is better developed.

The Hatchie terrace is similar to the Finley terrace in most other morphologic aspects. On all but the 
Loosahatchie and Wolf Rivers, it also exhibits distinctive nil gradients in its lower reaches (fig. 6). However, although the Hatchie terrace does approach floodplain levels because of the convergence of the gradients, it always remains at least a few meters above floodplain levels and nowhere is a buried feature. At the mouths of the rivers, the terrace elevations are between 10 and $15 \mathrm{~m}$ above the present flood plains. As can be seen in figure 6 , the Hatchie terrace has slightly lower average elevations upstream from the immediate mouths of the Obion, Hatchie, and Forked Deer Rivers and, thus, has "lip" features like the Finley terrace.

No beach-ridge features have been identified in association with the Hatchie terrace. Nevertheless, it is reasonable to interpret the downstream segments of this terrace on the Obion, Forked Deer, and Hatchie Rivers to be of lacustrine-plain origin like the downstream parts of the Finley terrace. Upstream where it has positive downstream gradients, the Hatchie terrace represents the relict flood plains of an earlier phase of the respective rivers.

On the Loosahatchie and Wolf Rivers, the Hatchie terrace lacks the evidence for lacustrine-plain origin as indicated above (fig. 6). A possible explanation for this lack involves the locus of rapid outwash deposition in the Mississippi alluvial valley responsible for the damming effect. Perhaps it was farther west in the valley some distance from the mouths of these rivers rather than right along the valley margin. Hence, backwater flooding and impoundment may have been absent along these rivers or less pronounced than impoundment along the Obion, Forked Deer, and Hatchie Rivers. Supporting this view is the observation that on the next four river systems south of Wolf River (the southernmost of which is $100 \mathrm{~km}$ from Wolf River), the lowest terrace has a positive downstream slope rather than a nil slope or reverse gradient. On the other hand, however, another explanation is that the terrace identified as the Hatchie terrace on the Loosahatchie and Wolf Rivers is actually a higher and older terrace that does not correlate with it. This problem is explored more fully in the next section of this paper.

The distribution of the Hatchie terrace within river systems is variable. Although it is evenly distributed along both sides of the Forked Deer and Wolf Rivers (figs. 3, 5), its distribution along the Obion, Hatchie, and Loosahatchie Rivers (figs. 2, 4,5) is highly asymmetrical. The reason for this asymmetry is not apparent. Structural control or uneven distribution of sediment-contributing tributaries sometimes can cause these conditions (Saucier and Fleetwood, 1970), but these factors do not appear to be influential in this area except locally.
Characteristics of the Hatchie terrace, especially its areal extent, suggest that the terrace formed during an unusually long period of geomorphological stability. If we exclude unlikely increases in the rates of fluvial activity or basin sediment yield, the inferred volume of sediments contained in the terrace suggests that it formed during a period considerably longer than that required for formation of the present (Holocene) flood plain.

An area of uncertain terrace identification involving the Hatchie terrace occurs between profile stations at 40 and $55 \mathrm{~km}$ along the North Fork of the Obion River (figs. 2,6). Two areas of terrace, one on each side of the river, have been mapped as Hatchie terrace; how ever, their reconstructed elevations are anomalously high in view of the trend of more downstream segments. The present most tenable explanation for this anomaly is local structural control. Shortly after the terrace mapping was completed, I learned that a pronounced scarp, oriented along a northeast-trending lineament, has been noted in this area and tentatively identified as a late Pleistocene fault (Tennessee University, Martin, 1981). The scarp is coincident with the northeast-trending Hatchie-Humboldt terrace contact south of Tennessee Highway 22 about $7.2 \mathrm{~km}$ southeast of Union City, Tenn. (fig. 2). Until more study is done, we can only speculate about the influence of this likely fault; however, it may have resulted in the downward displacement of a segment of this terrace on the order of 4 or $5 \mathrm{~m}$.

\section{HUMBOLDT TERRACE}

The Humboldt terrace is more difficult to map than the Hatchie and Finley terraces are because the exposures are smaller and less continuous and the surface is more dissected. Nevertheless, it has been identified on all but the Loosahatchie and Wolf Rivers (figs. 2-4). Its best exposure regionally is farthest to the north (Obion River) and declines southward. Geologists working in the region think that subsurface evidence indicates the presence of a higher terrace in the Memphis, Tenn., area that could be the Humboldt terrace (D.P. Russ, 1982, oral commun.). However, I could not map it on the basis only of physiographic evidence although I intuitively feel that it is there. In contrast, this terrace was not identified by Smith (1979), who did not extend his crossvalley profiles to elevations high enough to detect this terrace.

Morphologically, this terrace lacks any clues as to its mode of origin; it has no discernible features such as relict channels or meander-belt ridges or lake-shoreline features. Reasons for the lack of clues are postdepositional erosion, significant alluvial-apron development 
where the terrace abuts the uplands, and a loess veneer of unknown thickness.

As in the study of the other terraces, in this study, downvalley profiles present the most useful information. Figure 6 reveals that the reconstructed surfaces of the Humboldt terrace generally parallel the Holocene flood plains at a height of 10 to $20 \mathrm{~m}$. Downstream reduction in gradients occurs on the Obion and Forked Deer Rivers; however, now here does the terrace have a nil gradient. This lack of a nil gradient is interpreted to mean that lacustrine conditions due to backwater flooding from the Mississippi Valley did not exist or at least did not influence this terrace as it influenced the lower terraces. The Humboldt terrace is considered to be strictly a relict fluvial depositional feature.

Within any river system, the Humboldt terrace exposures are not noticeably asymmetrical. They occur on both sides of the present rivers, and their distribution indicates that the valleys were two to three times wider than at present when the Humboldt terrace was the active flood plain.

\section{HENDERSON TERRACE}

The Henderson terrace is limited to the upstream parts of the three forks of Forked Deer River (fig. 3). Its exposures are sufficient to make its identification as a terrace certain, and its relationship to the Humboldt terrace as a separate higher level is reasonably well established (fig. 6). Otherwise it provides more questions than answers.

Because it is the most highly dissected terrace, its restriction to the Forked Deer River may be only an artifact of the mapping procedure. On the other hand, as it is the oldest terrace, much of its original distribution may have been destroyed during subsequent cycles of valley degradation and aggradation and flood-plain formation.

\section{REGIONAL CORRELATIONS}

Construction of a generalized profile along the axis of the Mississippi alluvial valley, profile $\mathrm{A}-\mathrm{A}^{\prime}$ as located in figure 1, was necessary to correlate terraces among the tributaries and to establish relationships between these terraces and features in the alluvial valley resulting from major depositional events there. Two separate interpretations were derived from the data, each of which is plausible enough to warrant discussion. Figures 7 and 8 present the preferred and alternate interpretations of interstream correlations of terraces as they relate to the features in profile $\mathrm{A}-\mathrm{A}^{\prime}$.

Individual terrace and depositional-level profiles for the alluvial valley shown in these interpretations were constructed by projecting elevations on these surfaces to profile A-A' normal to the trend of this line (fig. 1). As was done in constructing the terrace profiles along the tributaries (fig. 6), judgment was used to reconstruct probable original maximum elevations. Such reconstruction was done for all the levels or terraces east of Crowleys Ridge that represent maximum levels of aggradation for various intervals during the Wisconsinan Stage as taken from Saucier (1974).

The part of the alluvial valley for which profile $A-\mathrm{A}^{\prime}$ was constructed received large volumes of glacial outwash from braided streams during the early waning stages of both the early Wisconsin (Altonian Substage) and late Wisconsin (Woodfordian Substage) glaciations (Saucier, 1974). Maximum valley aggradation occurred relatively early in each phase of waning glaciation when sediment loads were high, and degradation occurred subsequently as the ratio of sediment to melt water declined as the ice front receded northward. This cycle produced the several recognizable levels of outwash or braided-stream terraces that characterize the pre-Holocene parts of the St. Francis Basin (fig. 1). Flood plains or deposits older than the Wisconsinan Stage (for example, the Prairie terrace of the Sangamonian Stage) are absent in this area except for small erosional remnants at the mouths of small creeks on Crowleys Ridge. These are too few and too small to allow a profile to be constructed.

Profiles for the Finley, Hatchie, and Humboldt terraces shown in figures 7 and 8 represent interstream correlations of the elevations of these relict flood plains where they joined the Mississippi alluvial valley. The length of profile A- $\mathrm{A}^{\prime}$ was chosen to permit consideration of terraces and levels upvalley and downvalley beyond the mouths of the five rivers discussed. Southward, the profile extends $100 \mathrm{~km}$ beyond the mouth of the Wolf River so that the Little Tallahatchie River is included; northward, it extends about $25 \mathrm{~km}$ beyond the mouth of the Obion River so that Reelfoot Creek is included. I did not delineate any terraces on the several Mississippi River tributaries north of Reelfoot Creek in Kentucky, although some are reported to be present (D.P. Russ, 1982, oral commun.).

Figure 7 presents the terrace correlation I prefer as being relatively more consistent with the observed geomorphic evidence. However, this interpretation does pose possible problems as discussed below. This preferred interpretation was the basis for the designations of the terraces used in the mapping shown in figures 2 to 5 and the profiles shown in figure 6 .

As shown in figure 7, the lowest terrace on each of the five river systems is identified as the Finley terrace and the next highest one as the Hatchie 


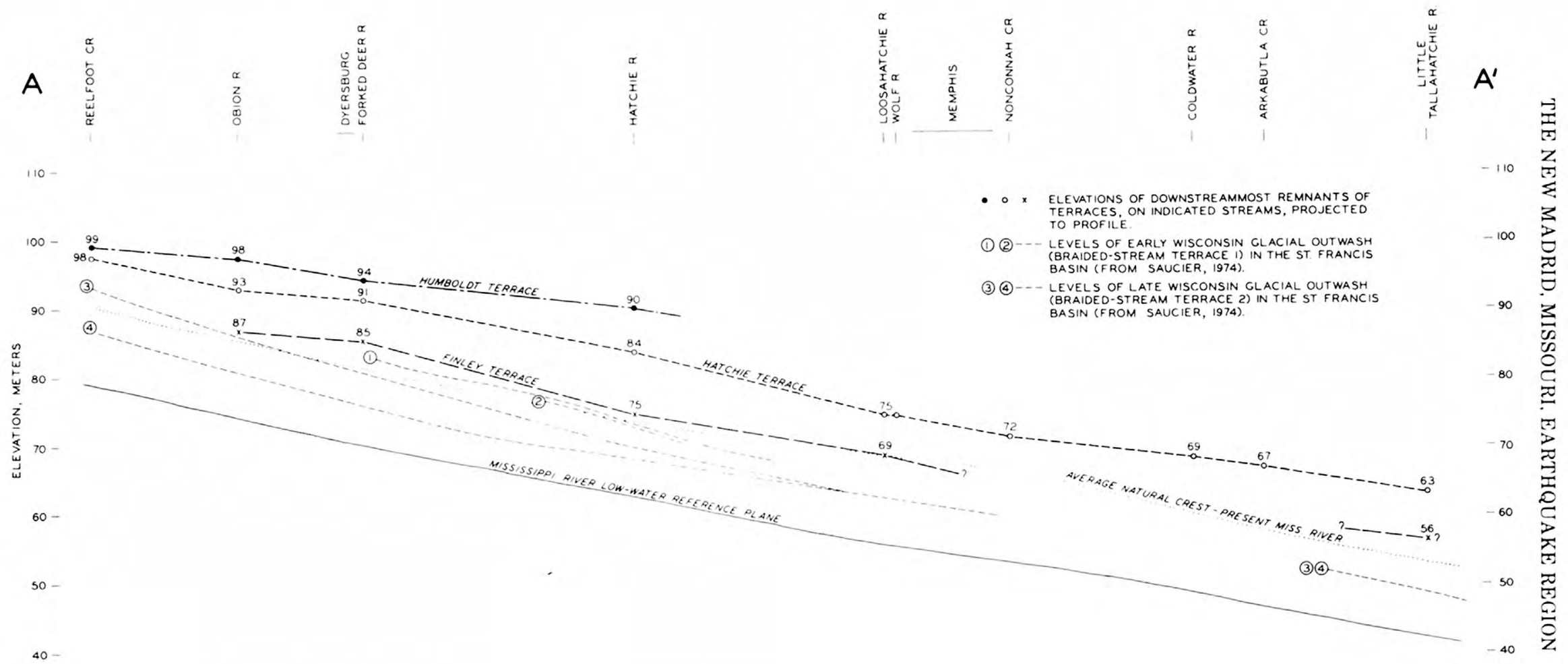




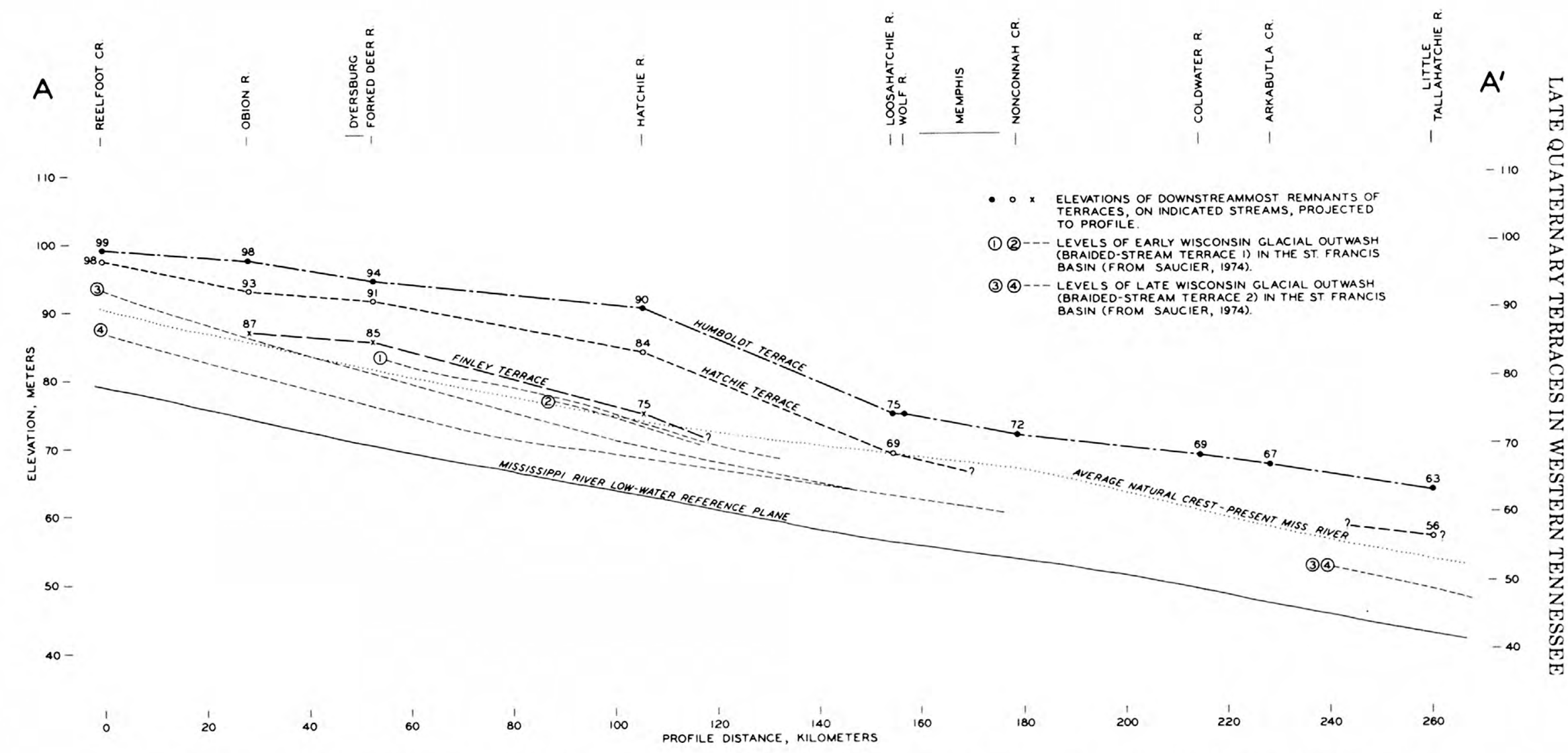

Figure 8.-North-south Mississippi Valley profile A-A'-alternate interpretation. Elevations in meters above mean sea level. For location of profile, see figure 1. 
terrace. Lines connecting the farthest downstream points on the terraces on each of the rivers produce smooth profiles that are comparable in configuration and slope to the braided-stream terraces and depositional levels in the Mississippi alluvial valley. This similarity is to be expected if the assumption is correct that events in the alluvial valley established the base levels to which the tributaries responded.

According to the interpretation in figure 7 , the Humboldt terrace is absent along all rivers south of the Hatchie River. Possible explanations for its absence are that the terrace never existed in this area, that it has been destroyed by erosion, or that it was unidentifiable by the mapping techniques discussed above. I believe that remnants of the Humboldt terrace are present south of the Hatchie River, but that because of the decreasing interfluve elevations and other factors, they are not recognizable on topographic maps and aerial photographs. Supporting this view is the opinion of others, based on field evidence, that remnants of this terrace may be present on both the Loosahatchie and Wolf Rivers (G.P. Smith and D.P. Russ, 1982, oral communs.).

In my opinion, another possible unresolved problem with, or weak point in, this interpretation (fig. 7) is the correlation, as the Hatchie terrace, of terraces on the Obion, Forked Deer, and Hatchie Rivers that have a nil gradient with ones on the Loosahatchie and Wolf Rivers that have a positive gradient in their lower reaches. It could be argued that all rivers should have responded similarly to sedimentation and flooding in the Mississippi alluvial valley. On the other hand, as discussed above, lakes may not have formed in the Loosahatchie and Wolf River valleys because they may have been too far from the locus of outwash deposition in the alluvial valley.

The alternate interpretation, depicted by the terrace correlations shown in figure 8 , alleviates these possible problems but presents others. The alternate interpretation differs from the preferred one primarily in the correlation of terraces along the Loosahatchie and Wolf Rivers. In the alternate interpretation, the higher terrace along these rivers (and along others to the south) is correlated with the Humboldt terrace rather than the Hatchie terrace, and the lower terrace along these rivers is correlated with the Hatchie terrace rather than the Finley terrace. What this alternate interpretation does is shift the need for an explanation of terrace absence from the Humboldt terrace to the Finley terrace, and a logical explanation is present. Figure 8 illustrates that, south of the Hatchie River, alluviation by the Mississippi River (within its present meander belt) and corresponding tributary-stream Holocene flood-plain aggradation have resulted in the lower terrace now being below present flood-plain level. Hence, the Finley terrace may be present but buried by Holocene alluvium.

A significant unexplained aspect of this alternate interpretation is the conspicuous upward deflection in the Humboldt and Hatchie terrace profiles at the Hatchie River (fig. 8). For both terraces, the elevations at this river are 5 to $6 \mathrm{~m}$ higher than what they would be if a smoother downvalley profile were assumed, as it was in the preferred interpretation (fig. 7).

Although a smoother profile would be the expected "normal" situation, an upward displacement near the Hatchie River is not without an explanation. It could be considered as evidence for continued or renewed structural uplift over an igneous intrusion (pluton) of Mesozoic age located beneath the Covington, Tenn., area (fig. 4). This and other plutons have been identified by gravity and magnetic surveys conducted as part of recent investigations of the origin and nature of the New Madrid seismic zone (Kane and others, 1981; Hildenbrand and others, 1977). They flank a nor theasttrending graben or rift that is the locus of the appreciable seismic activity in the region.

With the hypothesis of post-Mesozoic uplift in mind, we can discern apparently supporting evidence. For example, the course of the Hatchie River, which curves in a broad arc around the Covington area (fig. 4 ), is suspicious, as is the asymmetrical location of the Holocene flood plain along the northern flank of the overall Quaternary valley (farthest from the pluton). Moreover, the profile of the Humboldt terrace along the Hatchie River (fig. 6) has a constant downvalley slope rather than the more characteristic and normal concave-upward slope. This slope could be interpreted as evidence for uplift along the lower part of the Hatchie River.

Attention is now directed to the correlation of the terraces with events and features in the Mississippi alluvial valley. If the hypothesis is correct that extensive backwater flooding was a major factor in the formation of certain of the terraces, a close relationship should exist between farthest downstream terrace elevations and elevations of the braided-stream terraces in the St. Francis Basin area of the alluvial valley. Major periods of outwash deposition should have been coincident with times of maximum flood levels and also highest flood frequencies. Because of the relatively young geologic age of the braided-stream terraces and minimal postdepositional erosion or deposition, equivalency of elevation is considered to be a satisfactory basis for correlations.

According to either terrace interpretation, farthest downstream elevations on the Finley terrace closely approximate the elevations of the highest (early 
Wisconsinan Stage) braided-stream terrace (levels 1 and 2 in figures 7 and 8 ). That the Finley terrace may be a meter or two higher is not considered significant and may reflect only the loess veneer known to be present. Thus, the Finley terrace probably correlates in time with the early Wisconsinan Stage outwash.

If this correlation is valid, a late Wisconsinan Stage terrace should be present along the studied rivers as valley flooding and alluviation must have also accompanied this latest period of waning glaciation and outwash deposition. Such a terrace has not been recognized, but its apparent absence is not unexpected because, as can be seen in figures 7 and 8 , the levels of the late Wisconsinan Stage outwash (levels 3 and 4) lie below the average elevations of natural levee crests of the present Mississippi River meander belt. As this meander belt dominates the alluvial valley landscape near or at the mouths of all the upland streams under consideration, the average flood-plain surface in the tributaries is at or above that of a possible late Wisconsinan Stage terrace. Hence, if it is present, it is likely buried by a thin veneer of Holocene alluvium.

As mentioned in the section on terrace morphology, the Deweyville terrace is a widespread and distinctive physiographic feature on most streams in the Gulf of Mexico and Atlantic Coastal Plains. Few absolute dates are available to establish its chronological range, but evidence does indicate that it is definitely younger than mid-Wisconsinan (Farmdalian Substage) and older than Holocene (Saucier and Fleetwood, 1970; Saucier, 1974). More significantly, it formed during that part of the glacial-interglacial cycle in which the interaction of climate, landforms, and vegetation produced greatly increased stream discharges and sediment yields. This part of the cycle is believed to be coincident with waxing glaciation to near full glacial conditions and a time of widespread stream incision and valley degradation (Saucier, 1974; Grissinger and others, 1982).

A Deweyville terrace is not recognized on the rivers in western Tennessee. Nevertheless, the scallops formed along the Holocene flood-plain margin of the Finley terrace subsequent to terrace formation are thought to be a product of the climatic conditions prevailing when the Deweyville terrace formed. The absence of a Deweyville terrace is not unusual in that it could have been destroyed by subsequent stream meandering or veneered by a thin layer of Holocene alluvium as it was in other stream valleys (Gagliano and Thom, 1967; Saucier and Fleetwood, 1970).

If the terrace-margin scallops are the same age as the Deweyville terrace, they provide further evidence for the Finley terrace being pre-late Wisconsinan in age. Possibly the scallops and related features along the upland margin of the Finley terrace (which predate the terrace) are indicative of an unrecognized but not unex pected earlier episode of similar climatic response that occurred during waxing early Wisconsin glaciation. If these features did form then, they help substantiate that the Finley terrace formed during waning of the early Wisconsin glaciation.

Additional evidence for an early Wisconsinan Stage assignment of the Finley terrace occurs along Nonconnah Creek. Situated in the extreme southwest corner of Tennessee south of Memphis (figs. 1,5), this small stream, having a watershed of less than $500 \mathrm{~km}^{2}$, was not included in this terrace mapping effort because of its smallness and disturbance due to urbanization and channelization. However, as described by Delcourt and others (1980), a well-documented and dated measured section and fossil locality is present in the bank of the creek about $16 \mathrm{~km}$ upstream from the Mississippi alluvial valley. The 2.5 -m-thick deposit, representing a sedimentary sequence extending from the Altonian Substage through the Woodfordian Substage, is below the average level of the present creek flood plain. Extrapolation based on the Finley terrace profile in figure 7 indicates that this terrace at the fossil locality on Nonconnah Creek should be at or slightly below flood-plain level because of the amount of Holocene sedimentation in this area. Hence, there is excellent stratigraphic agreement between the Finley terrace and the recorded section.

According to the latest published views on lower Mississippi Valley Quaternary stratigraphy (Saucier, 1974), the next oldest (pre-Wisconsinan) and highest widespread interglacial-stage depositional unit is the Prairie terrace. Of Sangamonian age (Saucier, 1977), this terrace is areally significant in the valley south of the latitude of Memphis and shows evidence of a long period of regional stability in which thick sequences of meander-belt and backswamp deposits accumulated. Slow flood-plain aggradation must have persisted for thousands of years. No remnants of the Prairie terrace have been identified in the Mississippi alluvial valley north of Memphis. However, as mentioned above, small isolated areas of probable Prairie terrace survive in sheltered locations near the mouths of small creeks on Crowleys Ridge. In this area, they lie a few meters above the highest level of early Wisconsin outwash.

I postulate herein that the Hatchie terrace is a stratigraphic equivalent of the Prairie terrace and hence Sangamonian in age. The nil gradients and large extent of this terrace are certainly compatible with a long period of flood-plain aggradation in the Mississippi alluvial valley. However, it is quite possible that the downstream parts of the terrace exhibiting the nil gradient are not actually of lacustrine-plain 
origin as the downstream parts of the Finley terrace are. Prolonged flood-plain aggradation in the alluvial valley, acting as a slowly rising base level for a long period, could have produced a nil gradient in the tributaries. An absence of discernible shoreline features associated with the Hatchie terrace supports this view.

If the Hatchie terrace correlates with the Prairie terrace, the Humboldt terrace could be the equivalent of the Montgomery terrace. The Montgomery terrace is the next highest and most widespread interglacialstage fluvial terrace of the lower Mississippi Valley region (Fisk, 1939). Although concern is growing about the precise mode of origin and age of this terrace, it is still believed to be assignable to the Yarmouthian Stage (Saucier, 1974). Northernmost remnants of the Montgomery terrace occur north of the Grand Prairie region in eastern Arkansas (fig. 1); however, these are too far from the streams in western Tennessee to permit correlation based on elevations.

Fisk (1939) identified the Bentley and Williana terraces of the lower Mississippi Valley as major interglacial-stage depositional formations older than the Montgomery terrace. However, many workers in the area now seriously question the existence of these formations as Pleistocene depositional units (Saucier, 1974) or at least find correlations and age assignments to be impossible on the basis of existing evidence. Consequently, because of this uncertainty, it is not advisable to make any interpretation of the age of the Henderson terrace. In fact, I think that the geomorphic evidence alone is not sufficient to indicate that it is a Quaternary depositional formation.

\section{OVERVIEW}

This paper is the first attempt to systematically delineate and differentiate the late Quaternary deposits of western Tennessee associated with the present major upland drainage. Sound geomorphic evidence exists for a series of depositional terraces that have regional continuity and significance, although field verification and analyses of subsurface data have not been accomplished. Two interpretations of interstream correlations are presented, both of which indicate similar responses to external controls.

The most significant control affecting terrace formation processes and patterns along the lowermost several tens of kilometers of the streams studied was the deposition of glacial outwash in the Mississippi alluvial valley, which resulted in base-level changes. Understanding the direct and indirect responses of streams such as these to events in the alluvial valley is extremely important in refining interpretations of events within the alluvial valley itself. Because the alluvial valley has been an exceptionally dynamic environment characterized by repeated episodes of widespread scour and fill, major gaps must exist in the sedimentary record. Hence, one must look elsewhere for chronostratigraphic evidence. Detailed investigations of tributaries to the alluvial valley probably will contribute valuable information because the responses of the tributaries to scour and fill, although comparable in character to responses of the alluvial valley, probably were not of similar magnitude or duration.

Geologists have long recognized that the upper part of the Mississippi alluvial valley is an area of active Quaternary tectonism and seismicity (Fuller, 1912). However, almost all past geological studies of the area have focused on glacial- and interglacial-stage stratigraphy and chronology, depositional processes, and landform evolution and have contributed little to a needed understanding of earthquake causes and patterns (McKeown, 1982). Only within the last decade have significant and definitive contributions been made to knowledge of the origin, patterns, and rates of localized deformation involving faulting, upwarping, and tilting of Pleistocene and Holocene deposits in the New Madrid region (Russ, 1982). Nevertheless, the relationship of this deformation to regional Pleistocene uplift in terms of processes and timing is not well understood. Compounding the problem is the strikingly low rate of tectonic deformation as compared to rates in other regions (McKeown, 1982).

Information presented in this paper contributes in two respects toward an enhanced understanding of the regional aspects of Quaternary tectonism. First, it calls attention to a means of stratigraphic correlation that, in western Tennessee, has extended the range of possible indicators of regional deformation across a major physiographic boundary and well beyond the limits of the alluvial valley. Neither of the interpretations of terrace correlations indicates detectable Quaternary deformation in the upland area relative to the alluvial valley in the area studied. Similar terrace investigations and correlations need to be conducted elsewhere in the several-State area adjacent to the alluvial valley surrounding the New Madrid region.

Second, the information in this paper is relevant to detecting possible Quaternary deformation within the upland area itself. Detecting such deformation is important because of the presence of several plutons in the New Madrid region (McKeown, 1982), at least one of which has been studied in detail and found to have experienced active uplift at least as recent as the end of the Paleocene (Glick, 1982). The alternate interpretation of terrace correlations presented in this paper is suggestive of progressive uplift in the upland area in 
the vicinity of the Covington pluton; however, the preferred interpretation does not suggest uplift. Although I conclude, like Russ (1982), that the present upland physiography is primarily the result of normal erosional processes and not tectonism, further terrace investigations are necessary to arrive at a single viable interpretation, which may or may not suggest Quaternary deformation. Similar investigations in the vicinity of other plutons are necessary to better define their role in regional tectonism.

\section{REFERENCES CITED}

Cushing, E.M., Boswell, E.H., and Hosman, R.L., 1964, General geology of the Mississippi embayment: U.S. Geological Survey Professional Paper 448-B, 28 p.

Delcourt, P.A., Delcourt, H.R., Brister, R.C., and Lackey, L.E., 1980, Quaternary vegetation history of the Mississippi embayment: Quaternary Research, v. 13, no. 1, p. 111-132.

Finch, W.I., Olive, W.W., and Wolfe, E.W., 1964, Ancient lake in western Kentucky and southern Illinois, in Geological Survey research, 1964: U.S. Geological Survey Professional Paper 501-C, p. C130-C133.

Fisk, H.N., 1938, Geology of Grant and La Salle Parishes: Louisiana Geological Survey Geological Bulletin 10, 246 p.

1939. Depositional terrace slopes in Louisiana: Journal of Geomorphology, v. 2, no. 3, p. 181-200.

Fleetwood, A.R., 1969, Geological investigation of the Ouachita River area, lower Mississippi Valley: U.S. Army Corps of Engineers, Waterways Experiment Station Technical Report S-69-2, 24 p.

Fuller, M.L., 1912, The New Madrid earthquake: U.S. Geological Survey Bulletin 494, $119 \mathrm{p}$.

Gagliano, S.M., and Thom, B.G., 1967, Deweyville terrace, Gulf and Atlantic Coasts: Louisiana State University Coastal Studies Bulletin 1, p. 23-41.

Glick, E.E., 1982, Stratigraphy and structure of post-Paleozoic sediments above the Newport pluton of northeastern Arkansas, Chapter K of McKeown, F.A., and Pakiser, L.C., eds., Investigations of the New Madrid, Missouri, earthquake region: U.S. Geological Survey Professional Paper 1236, p. 151-174.

Grissinger, E.H., Murphey, J.B., and Little, W.C., 1982, LateQuaternary valley-fill deposits in north-central Mississippi: Southeastern Geology, v. 23, no. 3, p. 147-162.

Hildenbrand, T.G., Kane, M.F., and Stauder, William, 1977. Magnetic and gravity anomalies in the northern Mississippi embayment and their spacial relation to seismicity: U.S. Geological Survey Miscellaneous Field Studies Map MF-914, 2 sheets, scale $1: 1,000,000$.

Kane, M.F., Hildenbrand, T.G., and Hendricks, J.D., 1981, Model for the tectonic evolution of the Mississippi embayment and its contemporary seismicity: Geology, v. 9, no. 12, p. 563-568.

Leighton, M.M., and Willman, H.B., 1950, Loess formations of the Mississippi Valley: Journal of Geology, v. 58, no. 6, p. 599-623.

Lower Mississippi Region Comprehensive Study Coordinating Committee, 1974, Regional climatology, hydrology and geology, Appendix C of Lower Mississippi region comprehensive study: $2 \mathrm{v}$.

McKeown, F.A., 1982, Overview and discussion, Chapter A of Mckeown, F.A., and Pakiser, L.C., eds., Investigations of the New Madrid, Missouri, earthquake region: U.S. Geological Survey Professional Paper 1236, p. 1-14.

Miller, R.A., Hardeman, W.D., and Fullerton, D.S., compilers and eds., 1966, Geologic map of Tennessee, west sheet: Nashville, Tenn., Tennessee Division of Geology, scale 1:250,000.

Parks, W.S., 1971, Tertiary and Quaternary stratigraphy in Henry and northern Carroll Counties, Tennessee: Tennessee Academy of Science Journal, v, 46, no. 2, p. 57-62.

Potter, P.E., 1955, The petrology and origin of the Lafayette gravel. Pt. 2, Geomorphic history: Journal of Geology, v. 63, no. 2, p. 115-132.

Roberts, J.K., 1928, Tertiary stratigraphy of west Tennessee: Geological Society of America Bulletin, v. 39, no. 2, p. 435-446.

Russ, D.P., 1979, Late Holocene faulting and earthquake recurrence in the Reelfoot Lake area, northwestern Tennessee: Geological Society of America Bulletin, pt. 1, v. 90, no. 11, p. 1013-1018. 1982, Style and significance of surface deformation in the vicinity of New Madrid, Missouri, Chapter $\mathrm{H}$ of McKeown, F.A., and Pakiser, L.C., eds., Investigations of the New Madrid, Missouri, earthquake region: U.S. Geological Survey Professional Paper 1236, p. 95-114.

1984. Seismotectonics of the New Madrid seismic zone, central U.S.-Implications for intraplate earthquakes, in A collection of papers of International Symposium on Continental Seismicity and Earthquake Prediction: Beijing, China, Seismological Press, p. 312-324.

Saucier, R.T., 1964, Geological investigation of the St. Francis Basin [lower Mississippi Valley]: U.S. Army Corps of Engineers, Waterways Experiment Station Technical Report 3-659, $81 \mathrm{p}$

1974. Quaternary geology of the lower Mississippi Valley: Arkansas Archeological Survey Research Series 6, 26 p. 1977, The northern Gulf Coast during the Farmdalian Substage-A search for evidence: U.S. Army Engineer Waterways Experiment Station Miscellaneous Paper Y-77-1, $39 \mathrm{p}$.

Saucier, R.T., and Fleetwood, A.R., 1970, Origin and chronologic significance of late Quaternary terraces, Ouachita River, Arkansas and Louisiana: Geological Society of America Bulletin, v. 81, no. 3, p. 869-890.

Smith, G.P., 1979, Cultural resources survey of Hatchie National Wildlife Refuge, Tennessee: Unpublished report, available for consultation at U.S. National Park Service, Atlanta, Ga.

Tennessee University, Martin, 1981, Field trip log-Day 1, in Earthquakes and related features of the Mississippi River Valley-Symposium and field trip guides, Apr. 24-26, 1981, Program with abstracts: Martin, Tenn., no page numbers.

Wascher, H.L., Humbert, R.P., and Cady, J.G., 1948, Loess in the southern Mississippi Valley-Identification and distribution of the loess sheets: Soil Science Society of America Proceedings 1947 , v. 12, p. 389-399.

Zoback, M.D., 1979, Recurrent faulting in the vicinity of Reelfoot Lake, northwestern Tennessee: Geological Society of America Bulletin, pt. 1, v. 90, no. 11, p. 1019-1024. 



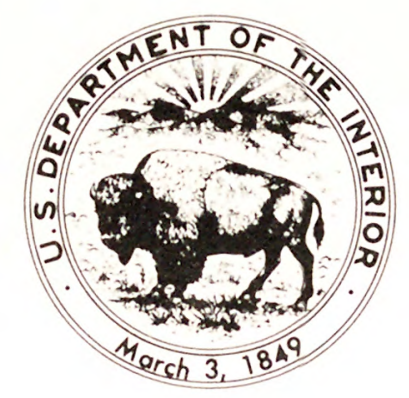

